\title{
Lorey height for vertical stratification of an Alluvial Ombrophilous Forest
}

\author{
Altura de Lorey para estratificación vertical de bosques naturales
}

\author{
Diego dos Santos Vieira ${ }^{\text {a*, }}$, Marcio Leles Romarco de Oliveira a, João Ricardo Vasconcelos Gama ${ }^{\text {b }}$ \\ Evandro Luiz Mendonça Machado a, Bruno Lafetá Oliveira c , Axa Simões Figueiredo ${ }^{\text {d }}$ \\ *Corresponding author: ${ }^{a}$ Federal University of Jequitinhonha and Mucuri Valleys, Department of Forestry, \\ Diamantina, Brazil, tel.: 55-93-991973755, diegovieir4@gmail.com \\ ${ }^{\mathrm{b}}$ Federal University of Para West, Department of Forestry, Santarém, Brazil. \\ ${ }^{c}$ Federal Institute of Education, Science and Technology of Minas Gerais, Department of Forestry, \\ São João Evangelista, Brazil. \\ ${ }^{\mathrm{d}}$ Forest Engineer, Master in Tropical Forest Science, Palmas, Brazil.
}

\begin{abstract}
SUMMARY
The method, which uses the arithmetic mean and standard deviation $\left(\mathrm{M}_{1}\right)$ of total heights $(\mathrm{Ht})$, is often used in the stratification of uneven-aged forests and assumes that the Ht must follow a normal standard curve considering a standard deviation of the mean. In cases where this assumption is rejected, alternative methods are used, such as the fundamentals in multivariate analysis $\left(\mathrm{M}_{2}\right)$ and Lorey's mean height $\left(\mathrm{M}_{3}\right)$. The objective was to evaluate the method M1 considering its assumption and comparing it with methods $\mathrm{M}_{2}$ and $\mathrm{M}_{3}$. The data were collected in 308 contiguous plots of $100 \mathrm{~m}^{2}$, installed in an Alluvial Ombrophylous Forest. The assumption of the method $M_{1}$ was analyzed adjusting a Normal Probabilistic Density Function, evaluated by the K-S test. The methods were evaluated using discriminant analyses, structural analyses and three-dimensional vertical profiles. It was verified that the assumption was not met. The discriminant analyses showed that the classification was $100 \%$ correct in methods $\mathrm{M}_{1}$ and $\mathrm{M}_{3}$. The 13 most important species, in descending order, were the same in all three methods. However, from the $13^{\text {th }}$, the differences were more remarkable in the method $M_{1}$. Firstly, it is recommended to use the method $M_{3}$, as it is more practical and provides results that are equal to those obtained using the method $\mathrm{M}_{2}$. However, if the objective is to obtain a higher level of detail, the option is the method $\mathrm{M}_{2}$ since it allows obtaining up to five strata with $100 \%$ correct classification.
\end{abstract}

Key words: total height, vertical strata, vertical structure, stratification methods.

\section{RESUMEN}

El método que usa la media aritmética y la desviación estándar de las alturas totales - Hts (M1) se usa a menudo en la estratificación de bosques con edades desiguales y supone que Hts debe seguir una curva estándar normal, considerando una desviación estándar de la media. En los casos en que se rechaza este supuesto, se utilizan métodos alternativos, como los fundamentos del análisis multivariado (M2) y la altura promedio de Lorey (M3). El objetivo de este estudio fue evaluar el método M1 considerando su suposición y comparándolo con los métodos M2 y M3. Los datos fueron recolectados en 308 parcelas contiguas de $100 \mathrm{~m}^{2}$. Hts se obtuvieron en base a una varilla medida. La suposición del método M1 se analizó ajustando una función de densidad probabilística normal, evaluada mediante la prueba K-S. Los métodos se evaluaron mediante análisis discriminante, análisis estructural y perfiles verticales tridimensionales. Se encontró que la suposición no se cumplió. Los análisis discriminantes mostraron que la clasificación era $100 \%$ correcta en los métodos M1 y M3. Las 13 especies más importantes, en orden decreciente, fueron las mismas en los tres métodos. Sin embargo, a partir del día 13, las diferencias fueron más notables en el método M1. Primero, se recomienda el uso del método M3, ya que es más práctico y proporciona los mismos resultados que los obtenidos por el método M2. Sin embargo, si el objetivo es obtener un mayor nivel de detalle, la opción es el método M2, ya que permite obtener hasta cinco estratos con una clasificación $100 \%$ correcta.

Palabras clave: altura total, estratos verticales, estructura vertical, métodos de estratificación.

\section{INTRODUCTION}

Structural studies are important indicators of the sustainability of forest activities (Souza et al. 2003) since they generate information about the dominance that certain species exert over others. This, in terms of competition for light, contributes to identifying the ecological behavior and habits of these species in the different height strata, thus allowing understanding the strategies of regeneration, growth and survival (Curto et al. 2013). This information is essential, among other things, for the definition of conservation policies, for degraded area recovery programs 
(Brito et al. 2007) and, above all, for the definition of silvicultural treatments and the assessment of impacts from logging activities (Calegário et al. 1994), thus encouraging more reliable forestry planning.

Although there is awareness of the importance of vertical structures for decision making, most studies that address the phytosociological characterization of forests in the Amazon only use tables of importance value that characterize horizontal structures and exclude vertical ones (Curto et al. 2013). The main reasons for its exclusion are the difficulty in analyzing them (Curto et al. 2013) and, mainly, the determination of the lower and upper limits of the strata, which are most often controversial and imperceptible (Durigan et al. 2000), with young trees of the upper stratum growing in the lower and mean strata. It is also worth noting that these limits are the basis for calculating the absolute and relative sociological positions and the extended importance values of the species, which characterize the vertical structures (Freitas y Magalhães 2012).

Several methods are used to define the boundaries of strata in unequal forests (Curto et al. 2013). The one described by Souza (1990) is one of the most used in the Amazon. This method is based on the use of the arithmetic mean and standard deviation of total heights $(\mathrm{Ht})$, so that the forest is divided into three strata: lower, mean and upper. The lower stratum comprises all trees with $\mathrm{Ht}$ lower than the mean of the Ht minus one unit of the standard deviation of the Ht, whereas the upper stratum includes the trees with height higher than the average of the Ht plus a unit standard deviation of the Ht. The mean stratum, in this case, comprises all trees between the lower and upper strata (Souza 1990).

These strata are conceptually and mathematically similar to the three area proportions under a standard normal curve, considering a standard deviation of the mean. Therefore, the percentage of values between plus and minus one standard deviation of the mean will be $68.2 \%$, while below and above a standard deviation of the mean will be $15.9 \%$, which will correspond to the middle, lower and upper strata of Souza (1990), respectively. Accordingly, if the Ht data obtained in forest inventories do not follow a standard normal curve, theoretically, Souza's method (1990) will be estimating the boundaries of the strata incorrectly and, consequently, the vertical structures of the forests will affect the decisions to be taken in the management or conservation activities.

The solution to this type of problem is the adoption of alternative methods, such as that described by Souza et al. (2003), which determines the strata by means of cluster and discriminant analyses. The objective of the cluster analysis is the identification of homogeneous and distinct groups called strata, which are formed by classes of $\mathrm{Ht}$ with previously determined amplitude; while the discriminant confirms the distinction and classification of the groups obtained in the cluster analysis (Souza et al. 2003, Souza y Souza 2004). The method of Souza et al. (2003) has shown characteristics that may be better than others of vertical stratification of unequal forests, although few studies in the Amazon use it due to the "popularity and practicality" of Souza's method (1990), which in most cases is applied without evaluating whether $\mathrm{Ht}$ data follow a standard normal curve.

Another acceptable solution is the reconciliation of $\mathrm{Ht}$ of trees with one or more measurement variables more accurate than height, for example, the diameter measured at $1.30 \mathrm{~m}$ from the soil (DBH), since the estimates of $\mathrm{Ht}$ are routinely obtained through visual estimates, which makes it more difficult to correctly identify the boundaries of strata. In addition, even if the $\mathrm{Ht}$ were obtained by means of equipment (e.g. hypsometers), these presuppose that the visualization is performed from the same point, from the base to the top of the tree, which is impracticable among Amazonian physiognomies (Durigan et al. 2000, Curto et al. 2013). Therefore, it also decreases the precision of the measurements and the definition of the strata. The height of Lorey (HL) would be an adequate option for this situation, since the arithmetic mean of $\mathrm{Ht}$ is weighted by the sum of the sectional areas, obtained from the DBH minimizing the influence of tall and thin trees as well as of low and thick trees in the calculation of mean height (Lorey 1878).

The hypotheses that guided this study were: $\mathrm{H}_{0}=\mathrm{Ht}$ data that follow normal curves can be stratified according to Souza (1990); $\mathrm{H}_{1}=\mathrm{Ht}$ data that do not follow normal curves can not be stratified according to Souza (1990); and $\mathrm{HL}$ and the method of Souza et al. (2003) demonstrate a more coherent stratification when the $\mathrm{H}_{0}$ hypothesis is rejected. Thus, the objective of this study is to evaluate the use of the Souza's method (1990) to obtain the boundaries of the vertical strata of a flooded forest in the Amazon, as well as to evaluate the use of Lorey height (Lorey 1878) and the method of Souza et al. (2003) as alternatives to cases where the Souza's method (1990) does not apply.

\section{METHODS}

Study area. The study was carried out on the Ilha da Paz Amazônica, in the areas of Tapajós National Forest. It is a section of periodically flooded forest with 3.08 ha, belonging to the community Jamaraquá, located at the geographic coordinates $2^{\circ} 49^{\prime} 07.24$ " $\mathrm{S}$ and $53^{\circ} 02^{\prime} 13.52^{\prime \prime} \mathrm{W}$, on the right bank of Tapajós River. The climate of the region, according to the classification of Köppen, is Ami, that is, humid tropical with annual thermal variation of less than $5^{\circ} \mathrm{C}$, average annual temperature of $25.5^{\circ} \mathrm{C}$, average relative humidity of $88 \%$ and average annual rainfall of $1,820 \mathrm{~mm}$ (Alvares et al. 2013). The forest typology is classified as Alluvial Ombrophylous Forest, with a period of flooding from December to June, while the ebbing period occurs between July and November (Santos et al. 2017).

Data collection. Data collection was performed by dividing the area into 308 contiguous sample units of $10 \times 10 \mathrm{~m}$ 
$\left(100 \mathrm{~m}^{2}\right)$, covering the largest possible floodable area. In each sample unit, all trees with diameters of $1.30 \mathrm{~m}$ of soil height $(\mathrm{DBH})$ equal to or higher than $10 \mathrm{~cm}$ were measured, identified and referenced in Cartesian coordinates $(\mathrm{X}, \mathrm{Y})$. Tree individuals that met the inclusion criteria and presented bifurcations below $1.30 \mathrm{~m}$ were evaluated as a single individual. In these cases, after registration of the diameters of each branch, the quadratic diameter formula (1) was used to determine the general diameter of the individual.

$$
d=\sqrt{d_{1}^{2}+d_{2}^{2}+d_{3}^{2}+\cdots+d_{n}^{2}}
$$

where: $\mathrm{d}=$ quadratic diameter $(\mathrm{cm})$ and $\mathrm{d}_{\mathrm{i}}=$ diameter of each branch.

Tree diameters were taken with the aid of a tape measure and the Ht were estimated visually, based on a metric rod. The bifurcated trees had only a measured height, which was that of the stem that presented higher Ht. Preliminary identification of the botanical material was done in the field at the species level and was later conferred, supplemented and corrected by specialists from the taxonomy and herbaria laboratory of the Federal University of the West of Pará. Classification of species followed the proposed system by Angiosperm Phylogeny Group III (Angiosperm Phylogeny Group 2009).

Data analyses. The total $\mathrm{Ht}$ were stratified by three methods. The first method $\left(M_{1}\right)$, proposed by Souza (1990), is based on the use of arithmetic mean and standard deviation of Ht. The limits of the lower, mean and upper strata obtained by this method were obtained by expressions (2), (3) and (4) respectively (Souza 1990).

$$
\begin{gathered}
\text { Lower stratum: } \mathrm{Ht}<\left(\mathrm{HT}_{\mathrm{m}}-1 \mathrm{~s}\right) \\
\text { Middle stratum: }\left(\mathrm{HT}_{\mathrm{m}}-1 \mathrm{~s}\right) \leq H t \leq\left(H t_{m}+1 s\right) \\
\text { Upper stratum: } \mathrm{Ht}>\left(\mathrm{Ht}_{\mathrm{m}}+1 \mathrm{~s}\right)
\end{gathered}
$$

where: $\mathrm{Ht}=$ total height of the trees sampled; $\mathrm{Ht}_{\mathrm{m}}=$ arithmetic mean of the total $\mathrm{Ht}$ of the trees sampled; and $\mathrm{s}=$ standard deviation of the total $\mathrm{Ht}$ of the trees sampled.

The $\mathrm{M}_{1}$ method evaluated if the Ht data followed a standard normal curve by adjusting a Normal Probability Density Function (PDF). If it does, it can be stated that the $\mathrm{M}_{1}$ method correctly classified the trees in the three strata of $\mathrm{Ht}$, since it describes the same proportion of values below a normal curve with more or less one standard deviation of the mean. If not, the method was inefficient and alternative methods are recommended. The PDF parameters were estimated by the maximum likelihood method, and the quality of the fit was evaluated using the KolmogorovSmirnov adhesion test, at $95 \%$ probability.
The second method $\left(\mathrm{M}_{2}\right)$ is based on the use of the cluster analysis (Souza et al. 2003). In this method, trees were initially organized in ascending order of $\mathrm{Ht}$, to later be grouped into classes with a width of $1.0 \mathrm{~m}$. Afterwards, an $\mathrm{X}$ data matrix of $\mathrm{Ht}$ was elaborated, where each variable $\mathrm{X}_{\mathrm{ij}}$ represented the height of the $\mathrm{i}$-th tree classified in the $\mathrm{j}$-th height class (Souza et al. 2003). The matrix X was the input for the cluster analysis. The clustering criteria used to obtain the groups composed of classes of $\mathrm{Ht}$, called $\mathrm{Ht}$ strata, were the euclidean distance $(5,6)$ and the Ward method (Souza et al. 2003). The Ht strata were determined by plotting a cut line on the dendrogram resulting from the cluster analysis. The line was drawn so as to form three Ht strata, therefore comparisons between methods would be possible since the other methods necessarily describe three strata.

$$
\begin{gathered}
d_{i j}=\sqrt{\sum_{h=1}^{p}\left(x_{h i}-x_{h j}\right)}, h=1,2,3, \cdots, P \\
d_{i j}^{2}=\left(x_{i}-x_{j}\right)^{2}
\end{gathered}
$$

where: $\mathrm{d}_{\mathrm{ij}}=$ estimated Euclidean distance between classes $\mathrm{i}$ and $\mathrm{j} ; \mathrm{x}_{\mathrm{hi}}=$ diameter of the ith class in the ith class of diameter; $\mathrm{x}_{\mathrm{hj}}=$ diameter of the ith class in the jth class of diameter; and $\mathrm{d}_{\mathrm{ij}}^{2}=$ distance between the means of groups I and $\mathrm{J}$.

The third method $\left(\mathrm{M}_{3}\right)$ is an adaptation of the $\mathrm{M}_{1}$ method, so that the arithmetic mean of the total $\mathrm{Ht}$ is replaced by the mean height of Lorey $\left(\mathrm{H}_{\mathrm{L}}\right)$ (Lorey 1878), obtained by means of the expression (7). Therefore, lower, mean and upper strata were obtained according to expressions (8), (9) and (10), respectively.

$$
\begin{gathered}
\mathrm{H}_{\mathrm{L}}=\frac{\sum_{\mathrm{i}=0}^{\mathrm{n}} \mathrm{Ht}_{\mathrm{i}} \cdot \mathrm{g}_{\mathrm{i}}}{\sum_{\mathrm{i}=0}^{\mathrm{n}} \mathrm{g}_{\mathrm{i}}}, \text { where } \mathrm{g}_{\mathrm{i}}=\frac{\pi \cdot \mathrm{DBH}^{2}}{40,000} \\
\text { Lower stratum: } \mathrm{Ht}<\left(\mathrm{H}_{L}-1 \mathrm{~s}\right) \\
\text { Middle stratum: }\left(\mathrm{H}_{\mathrm{L}}-1 \mathrm{~s}\right) \leq H t \leq\left(H_{L}+1 s\right) \\
\text { Upper stratum: } \mathrm{Ht}<\left(\mathrm{H}_{\mathrm{L}}+1 \mathrm{~s}\right)
\end{gathered}
$$

where: $H_{L}=$ mean Lorey height of the trees sampled (m); $\mathrm{g}_{\mathrm{i}}=$ sectional area of the ith tree $\left(\mathrm{m}^{2}\right) ; \mathrm{DBH}=$ diameter at $1.30 \mathrm{~m}$ from the soil of the $\mathrm{i}$-th tree $(\mathrm{cm})$; and $\mathrm{Ht}$ and $\mathrm{s}=$ defined above.

The three methods were evaluated through Fisher's discriminant analysis, which aimed at evaluating the number of correct classification of methods $\mathrm{M}_{1}, \mathrm{M}_{2}$ and $\mathrm{M}_{3}$, and comparative analyses of vertical structures, which were obtained according to Freitas and Magalhães (2012), and by means of vertical profiles. In relation to vertical structures, only the parameters absolute sociological position (PSA) 
and expanded importance value (VIA) were compared, since the others, frequency (FA), density (DA) and absolute dominance (DoA), are the same in all the methods. The parameters FA, DA and DoA make up the horizontal structure and were analyzed for complementing the vertical analysis within the phytosociological study of the forest. It was also evaluated, for each species and for the community, if the number of trees in the strata was different among $\mathrm{M}_{1}, \mathrm{M}_{2}$ and $\mathrm{M}_{3}$. The test applied, in this case, was the chi-square for contingency tables, at $95 \%$ probability (Zar 1996).

Throughout the results and discussions, the words lower, mean and upper will be followed by the subscripts ${ }_{\mathrm{M} 1},{ }_{\mathrm{M} 2}$ and ${ }_{\mathrm{M} 3}$, which respectively signify methods $\mathrm{M}_{1}, \mathrm{M}_{2}$ and $\mathrm{M}_{3}$. Therefore, the words mean ${ }_{\mathrm{M} 1}$, mean $_{\mathrm{M} 2}$ and mean ${ }_{\mathrm{M} 3}$ imply that the mean strata were obtained using $M_{1}, M_{2}$ and $M_{3}$, respectively. The data were processed in software $R$ version 3.3.2 (R Core Team 2018), using the scatterplot3d package (Ligges and Mächler 2003), for the construction of vertical profiles, and vegan (Oksanen et al. 2018), for cluster and discriminant analyses. Adjustment of Normal PDF and chi-square test were performed using the software Easy Fit and Microsoft Excel 2016, respectively.

\section{RESULTS}

The values of the arithmetic mean and the standard deviation of Ht were 10.1 and $4.05 \mathrm{~m}$, respectively. The $\mathrm{M}_{1}$ showed that the lower $_{\mathrm{M} 1}$ stratum was constituted by trees of 4.0 to $5.9 \mathrm{~m}$ height and added up to $16.0 \%$ of trees. Regarding mean ${ }_{\mathrm{M} 1}$, it covered all trees with height of 6.0 to $13.9 \mathrm{~m}$, accounting for $71.3 \%$ of the inventoried trees (ta- ble 1). The upper ${ }_{\mathrm{Ml}}$, in turn, included trees with height of 14.0 to $25.1 \mathrm{~m}$, adding up to $12.7 \%$ of the trees. It was also observed that although the strata of the $M_{1}$ method should represent the three area proportions under a standard normal curve, plus or minus one standard deviation of the mean, there is a surplus of 0.15 and $3.03 \%$ of trees in the lower $_{\mathrm{M} 1}$ and mean ${ }_{\mathrm{M} 1}$, respectively, and a deficit of $3.08 \%$ in the upper ${ }_{\mathrm{M} 1}$. The results of the discriminant analysis showed significant differences $(\mathrm{F}=28.387)$, with Wilk's Lambda values close to zero and probabilities of 0.095 , 0.381 and 0.524 for the lower $_{\mathrm{Ml}}$, mean $_{\mathrm{M} 1}$ and upper $_{\mathrm{M} 1}$ strata respectively. The confusion matrix showed that $95.2 \%$ of the Ht classes were correctly identified in the vertical strata of the $M_{1}$ method (table 1).

The histogram with the distribution of Ht showed that the area has a high abundance of trees in the initial classes, with a reduction in the larger classes (figure 1A). However, from a statistical point of view, this behavior was not described by a Normal Probability Density Function, since the Ht distribution deviated significantly from a normal distribution, as verified by the Kolmogorov-Smirnov test, which showed that the value in $\mathrm{D}_{\text {calc }}(0.170)$ was greater than $\mathrm{D}_{\text {tab }}(0.042)$, to $95 \%$ probability. In addition, trends of under and overestimation of the number of trees in different height clases were observed.

The $\mathrm{M}_{2}$ method considering the dendrogram with a cut line at a euclidean distance equal to 100 , registered three homogeneous and distinct groups called strata lower ${ }_{\mathrm{M} 2}$, mean $_{\mathrm{M} 2}$ and upper ${ }_{\mathrm{M} 2}$ (figure 1B). The lower ${ }_{\mathrm{M} 2}$ covered the first eight height classes, with a range of 4.0 to $10.9 \mathrm{~m}$, while the mean ${ }_{\mathrm{M} 2}$ included classes 9 to 16 , ranging from

Table 1. Amplitude of the strata and matrix of confusion of the methods $\mathrm{M}_{1}, \mathrm{M}_{2}$, and $\mathrm{M}_{3} \mathrm{~N}=$ number of trees per $\mathrm{Ht}$ stratum; $P=$ priori probabilities.

Amplitud de los estratos y matriz de confusión de los métodos $\mathrm{M}_{1}, \mathrm{M}_{2} \mathrm{y} \mathrm{M}_{3} \cdot \mathrm{N}=$ número de árboles por estrato Ht; $P$ = probabilidad a priori.

\begin{tabular}{|c|c|c|c|c|c|c|c|c|c|}
\hline \multirow{2}{*}{ Method } & \multirow{2}{*}{ Stratum } & \multirow{2}{*}{ Amplitude (m) } & \multirow{2}{*}{$\mathrm{N}$} & \multirow{2}{*}{$P$} & \multicolumn{3}{|c|}{ Classification } & \multirow{2}{*}{ Sum } & \multirow{2}{*}{ Hit $(\%)$} \\
\hline & & & & & Lower $_{\mathrm{M} 1}$ & Average $_{\mathrm{M} 1}$ & Upper $_{\mathrm{M} 1}$ & & \\
\hline \multirow{3}{*}{$\mathrm{M}_{1}$} & Lower $_{\mathrm{M} 1}$ & $4.0-5.9$ & 163 & 0.095 & 1 & 0 & 0 & 1 & 100 \\
\hline & Average $_{\mathrm{M} 1}$ & $6.0-13.9$ & 729 & 0.381 & 1 & 8 & 0 & 9 & 88.9 \\
\hline & Upper $_{\mathrm{M} 1}$ & $14.0-25.1$ & 130 & 0.524 & 0 & 0 & 11 & 11 & 100 \\
\hline & Sum & - & 1022 & & 2 & 8 & 11 & 21 & 95.2 \\
\hline \multirow{3}{*}{$\mathrm{M}_{2}$} & Lower $_{\mathrm{M} 2}$ & $4.0-10.9$ & 703 & 0.333 & 7 & 0 & 0 & 7 & 100 \\
\hline & Average $_{\mathrm{M} 2}$ & $11.0-19.9$ & 274 & 0.429 & 0 & 9 & 0 & 9 & 100 \\
\hline & Upper $_{\mathrm{M} 2}$ & $20.0-25.1$ & 45 & 0.238 & 0 & 0 & 5 & 5 & 100 \\
\hline & Sum & - & 1022 & & 7 & 9 & 5 & 21 & 100 \\
\hline \multirow{3}{*}{$\mathrm{M}_{3}$} & Lower $_{\mathrm{M} 3}$ & $4.0-9.9$ & 555 & 0.286 & 6 & 0 & 0 & 6 & 100 \\
\hline & Average $_{\mathrm{M} 3}$ & $10.0-17.9$ & 393 & 0.381 & 0 & 8 & 0 & 8 & 100 \\
\hline & Upper $_{\mathrm{M} 3}$ & $18.0-25.1$ & 74 & 0.333 & 0 & 0 & 7 & 7 & 100 \\
\hline \multicolumn{2}{|r|}{ Sum } & - & 1022 & - & 6 & 8 & 7 & 21 & 100 \\
\hline
\end{tabular}




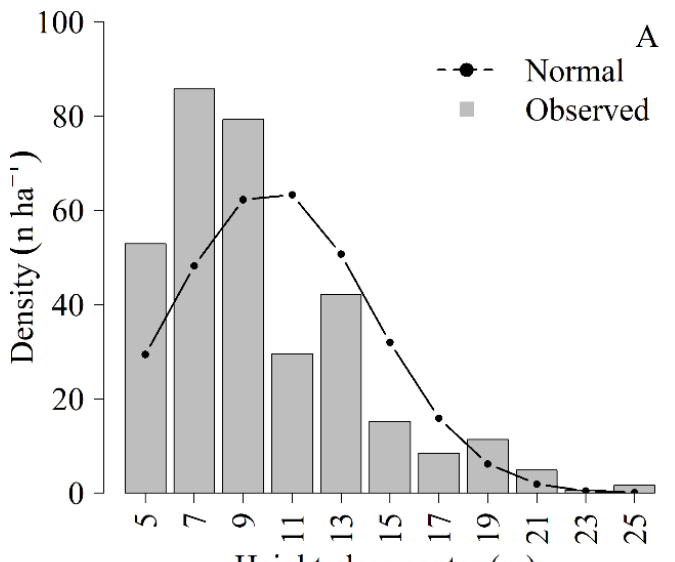

Height class center $(\mathrm{m})$

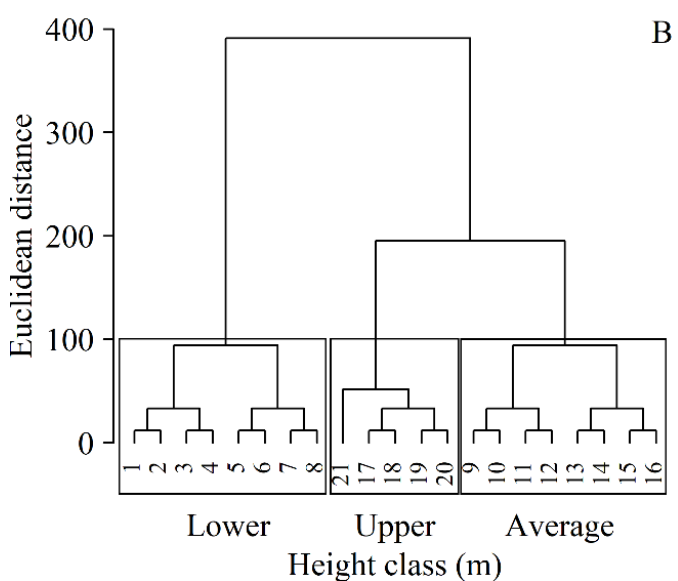

Figure 1. Distribution curve of the tree density obtained by the Normal PDF of the M1 method (A) and dendrogram of the cluster analysis of the $\mathrm{M}_{2}$ method (B).

Curva de distribución de la densidad arbórea obtenida por el FDP normal del método M1 (A) y dendrograma del análisis de conglomerados del método $\mathrm{M}_{2}(\mathrm{~B})$.

11.0 to $19.9 \mathrm{~m}$. The upper ${ }_{\mathrm{M} 2}$, in turn, encompassed classes 17 through 21, resulting in an amplitude of 20.0 to $25.1 \mathrm{~m}$. The lower ${ }_{\mathrm{M} 2}$, mean ${ }_{\mathrm{M} 2}$ and upper ${ }_{\mathrm{M} 2}$ strata, $68.8 \%, 26.8 \%$ and $4.4 \%$ of the trees. The discriminant analysis showed significant differences $(\mathrm{F}=64.723)$, with Wilk's Lambda values close to zero and probabilities of $0.333,0.429$ and 0,238 for lower $_{\mathrm{M} 2}$, mean $_{\mathrm{M} 2}$ and upper ${ }_{\mathrm{M} 2}$ strata, respectively. The confusion matrix showed that $100 \%$ of the Ht classes were correctly classified in the strata of the method $\mathrm{M}_{2}$ (table 1).

The $\mathrm{M}_{3}$ method demonstrated that the mean height of Lorey $\left(\mathrm{H}_{\mathrm{L}}\right)$ and the standard deviation of $\mathrm{Ht}$ were 14.0 and $4.05 \mathrm{~m}$, respectively. Therefore, the lower $_{\mathrm{M} 3}$ stratum was composed of trees with 4.0 to $9.9 \mathrm{~m}$ in height and added up to $54.3 \%$ of the trees, while the mean ${ }_{\mathrm{M} 3}$ covered all tree individuals with a height of 10.0 to $17.9 \mathrm{~m}$, making up $38.5 \%$ of the trees sampled. The upper ${ }_{\mathrm{M} 3}$, in turn, included trees with a height of 18.0 to $25.1 \mathrm{~m}$, accounting for 7.2 $\%$ of tree individuals. The discriminant analysis showed significant differences $(\mathrm{F}=62.542)$, with Wilk's Lambda values close to zero and probabilities of $0.286,0.381$ and 0.333 for lower $_{\mathrm{M} 3}$, mean ${ }_{\mathrm{M} 3}$ and upper ${ }_{\mathrm{M} 3}$ strata, respectively. The classification procedure showed that $100.0 \%$ of the $\mathrm{Ht}$ classes were correctly identified in the Ht strata (table 1). The vertical profiles clearly showed a greater similarity between the strata of $\mathrm{Ht}$ obtained by the methods $\mathrm{M}_{2}$ and $\mathrm{M}_{3}$, with differences between the lower and upper limits of up to $2.0 \mathrm{~m}$, while in the method $\mathrm{M}_{1}$ these differences ranged from 4.0 to $6.0 \mathrm{~m}$ (figure 2).

The vertical structures, regardless of the stratification method, showed the same frequencies (FA), densities (DA) and absolute dominances (DoA) for all species, changing only their density in strata, absolute sociological position (PSA) and importance value (VIA) (table 2). The ten species of higher densities $\left(\mathrm{DA} \geq 7.79\right.$ trees $\left.\mathrm{a}^{-1}\right)$ in the com- munity, in descending order, were Campsiandra laurifolia, Glycoxylon pedicellatum, Hevea brasiliensis, Tetragastris altissima, Mabea caudata, Vantanea parviflora, Swartzia sp., Inga capitata, Inga auristellae and Couepia hoffmaniana, which together account for $70.8 \%$ of all the DA. The ten most dominant species (DoA $\geq 0.389 \mathrm{~m}^{2} \mathrm{ha}^{-1}$ ), in descending order, were Hevea brasiliensis, Campsiandra laurifolia, Glycoxylon pedicellatum, Inga capitata, Tetragastris altissima, Vataireopsis speciosa, Vantanea parviflora, Inga auristellae, Nectandra sp. and Sideroxylon obtusifolium, which together account for $68.5 \%$ of all DoA.

The ten species of higher density $(\mathrm{DA} \geq 4.22$ trees ha-1) in lower ${ }_{\mathrm{M} 2}$ stratum, in descending order, were Campsiandra laurifolia, Mabea caudata, Glycoxylon pedicellatum, Vantanea parviflora, Tetragastris altissima, Swartzia sp., Conepia hoffmaniana, Pera glabrata, Guarea guidonia and Inga capitata. The same species were the densest (DA $\geq 2.92$ trees $\mathrm{ha}^{-1}$ ) in lower ${ }_{\mathrm{M} 3}$ stratum, but not in exactly the same order. The first five, in this case, in descending order, were Campsiandra laurifolia, Mabea caudata, Vantanea parviflora, Glycoxylon pedicellatum and Tetragastris altissima. The lower ${ }_{\mathrm{M} 1}$ stratum. in turn, exhibited as more dense $(\mathrm{DA} \geq 0.97$ trees ha-1), in descending order, the species Campsiandra laurifolia, Glycoxylon pedicellatum, Tetragastris altissima, Hevea brasiliensis, Vantanea parviflora, Mabea caudata, Swartzia sp., Inga capitata, Inga auristellae and Couepia hoffmaniana.

The ten species of higher density (DA $\geq 1.95$ trees $\mathrm{ha}^{-1}$ ) in the mean $\mathrm{M}_{2}$ stratum, in descending order, were Hevea brasiliensis, Glycoxylon pedicellatum, Tetragastris altissima, Campsiandra laurifolia, Coccoloba latifolia, Inga auristellae, Inga capitata, Vantanea parviflora, Myrciaria floribunda and Brosimum guianense. The same species were the ten most dense $\left(\mathrm{DA} \geq 3.89\right.$ trees $\left.\mathrm{ha}^{-1}\right)$ in the mean ${ }_{\mathrm{M} 3}$ strata, but not exactly in the same sequence. 

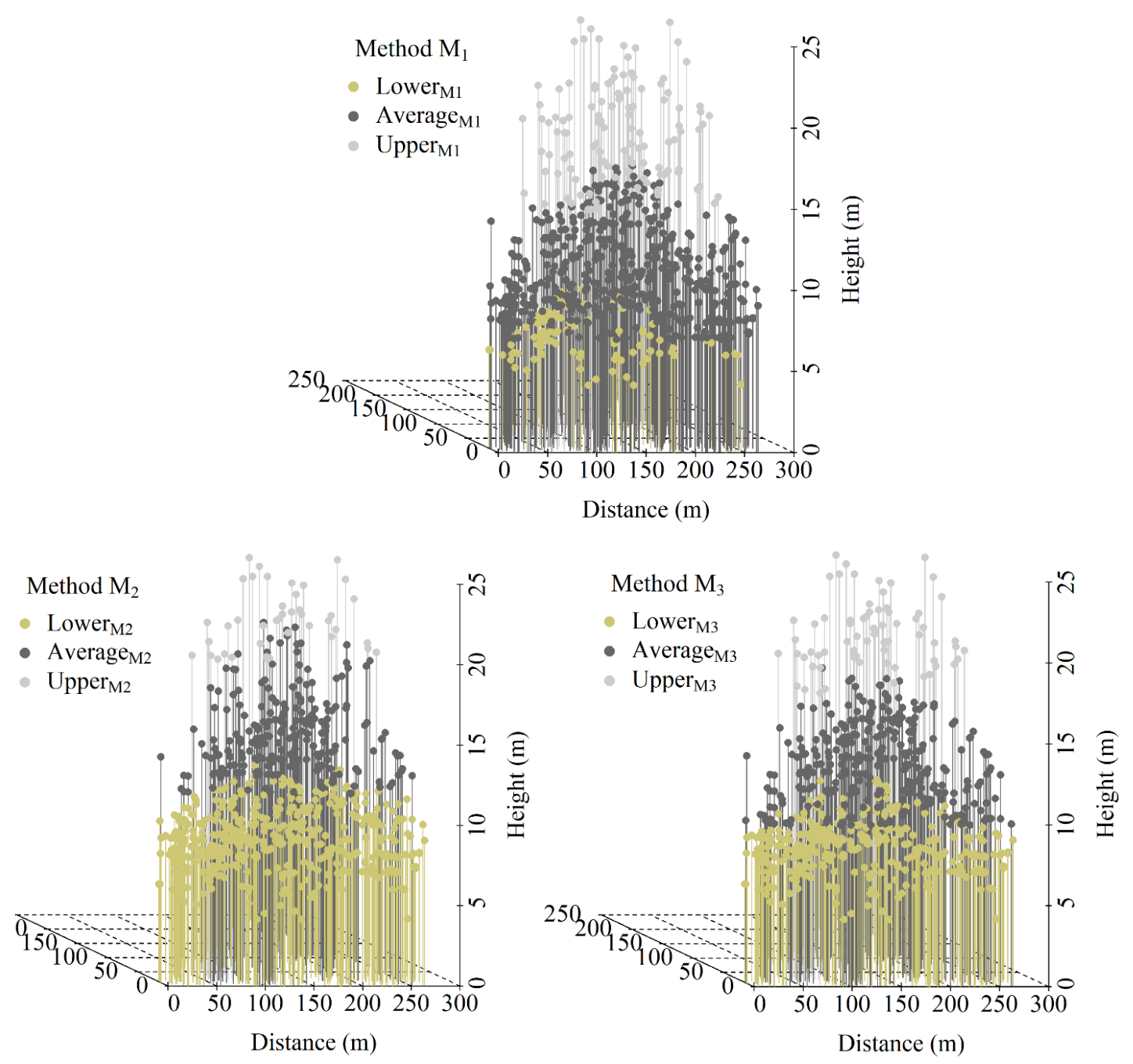

Figure 2. Illustration of the strata of Ht obtained by the methods M1, M2 and M3.

Ilustración de los estratos de Ht obtenidos por los métodos M1, M2 y M3.

Campsiandra laurifolia was the first in the DA ranking, followed by the species Glycoxylon pedicellatum, Tetragastris altissima, Hevea brasiliensis and Inga auristellae. The mean $_{\mathrm{M} 1}$ stratum, in turn, presented as more dense (DA $\geq 5.84$ trees ha $^{-1}$ ), in descending order, the species Campsiandra laurifolia, Glycoxylon pedicellatum, Tetragastris altissima, Hevea brasiliensis, Vantanea parviflora, Mabea caudata, Swartzia sp., Inga capitata, Inga auristellae and Couepia hoffmaniana (table 2).

The ten species of higher density ( $\mathrm{DA} \geq 0.325$ trees ha $^{-1}$ ) in the upper ${ }_{\mathrm{M} 2}$ stratum, in descending order, were Hevea brasiliensis, Vataireopsis speciosa, Nectandra sp., Tapirira guianensis, Dialium guianense, Glycoxylon pedicellatum, Sideroxylon obtusifolium, Vantanea parviflora, Dipteryx polyphylla and Licania kunthiana. The same species were among the densest (DA $\geq 3.89$ trees $\mathrm{ha}^{-1}$ ) in the upper ${ }_{\mathrm{M}}$ strata, except the tenth, which was replaced by the species Crudia pubescens. The first five, in this case, in descen- ding order, were Hevea brasiliensis, Dialium guianense, Glycoxylon pedicellatum, Vataireopsis speciosa and Tapirira guianensis. The upper stratum $\mathrm{M}_{1}$, on the other hand, presented density $\left(\mathrm{DA} \geq 0.65\right.$ trees $\mathrm{ha}^{-1}$ ), in descending order, the species Hevea brasiliensis, Coccoloba latifolia, Glycoxylon pedicellatum, Inga auristellae, Nectandra sp., Tapirira guianensis, Dialium guianense, Sideroxylon obtusifolium, Vataireopsis speciosa and Vantanea parviflora.

The species of higher PSAs in the structure, calculated by the $\mathrm{M}_{2}$ method, in descending order, were Campsiandra laurifolia, Glycoxylon pedicellatum, Mabea caudata, Tetragastris altissima, Vantanea parviflora, Hevea brasiliensis, Swartzia sp., Couepia hoffmaniana, Pera glabrata and Inga capitata. The first seven species of this method, in descending order, were also the same in the structure of the method $\mathrm{M}_{3}$, followed by Inga capitata, Couepia hoffmaniana and Inga auristellae. The highest PSAs in the structure of the method $\mathrm{M}_{1}$, in descending order, were Camp- 


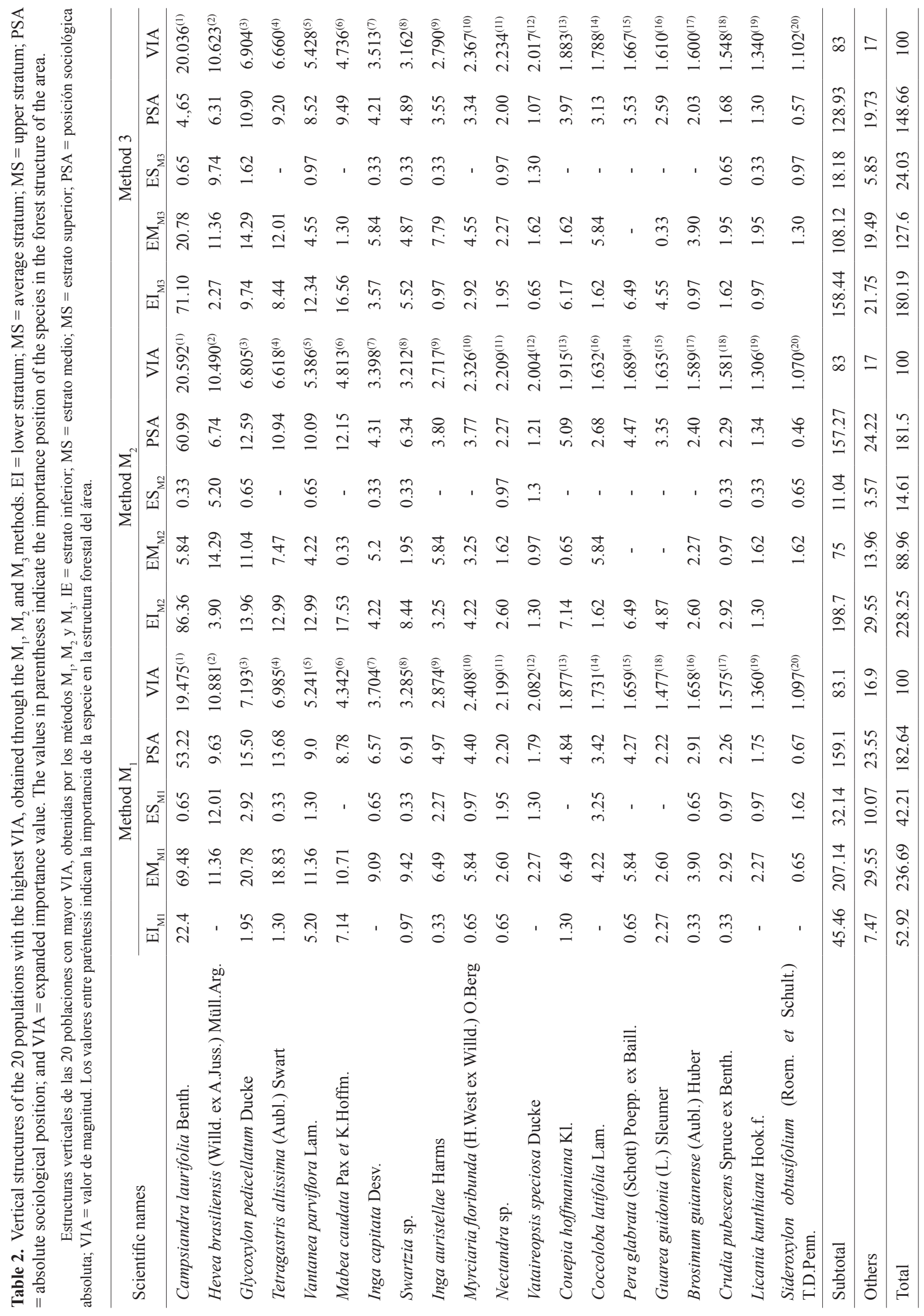


siandra laurifolia, Glycoxylon pedicellatum, Tetragastris altissima, Mabea caudata, Hevea brasiliensis, Vantanea parviflora, Mabea caudata, Swartzia sp., Inga capitata, Inga auristellae and Couepia hoffmaniana.

The 13 species with the highest VIA values, in descending order, were: Campsiandra laurifolia, Hevea brasiliensis, Glycoxylon pedicellatum, Tetragastris altissima, Vantanea parviflora, Mabea caudata, Inga capitata, Swartzia sp., Inga auristellae, Myrciaria floribunda, Nectandra sp., Vataireopsis speciosa and Couepia hoffmaniana, which together added $72.5,73.4$ and $72.5 \%$ of the entire VIA of the vertical structures obtained by methods of $\mathrm{M}_{1}$ and $\mathrm{M}_{3}$, respectively, maintained the same positions recorded in the method $\mathrm{M}_{2}$, while the others changed, on average, two positions to more or less (table 2).

The chi-square test for contingency tables showed that the number of community trees in the lower, mean and upper strata is dependent on the selected stratification method, since the values of the $\chi^{2}$ calculated were higher than the $\chi^{2} 95 \%$ probability (table 3 ). The same test also showed that for 46 species no differences were recorded between the number of trees in the three strata of Ht obtained by methods $M_{1}, M_{2}$ and $M_{3}$. The other species, showed in table 3, presented significant differences in at least one of the Ht strata. The species Campsiandra laurifolia, for example, showed differences in the number of trees for the lower and mean strata obtained by the three methods, indicating that the number of trees was dependent on the stratification method, whereas among the upper stratum no dependence was recorded. The same occurred for the species Glycoxylon pedicellatum, Tetragastris altissima, Vantanea parviflora and Swartzia sp., all located among the nine most important species of the Ilha da Paz Amazônica.

\section{DISCUSSION}

The vertical strata were better estimated in methods $\mathrm{M}_{2}$ and $\mathrm{M}_{3}$. The certainty of their higher efficiencies was corroborated by the discriminant analysis, which demonstrated that $100 \%$ of the Ht classes were correctly classified in the lower, mean and upper strata, while in the method $M_{1}$ the percentage was $95.2 \%$. The same finding was observed by Curto et al. (2013) that, comparing different methods in a Semideciduous Seasonal Forest in the municipality of Guaçuí, Espírito Santo, concluded that the method $\mathrm{M}_{2}$ was one of the most efficient, while the method $\mathrm{M}_{1}$ did not allow a detailed analysis on the behavior of the species in the mean stratum, due to the strong tendencies of concentrating more trees in the said stratum, thus hindering interpretations.

The high number of trees Campsiandra laurifolia and Mabea caudata in the lower ${ }_{\mathrm{M} 3}$ stratum also corroborates the efficiency of methods $\mathrm{M}_{2}$ and $\mathrm{M}_{3}$, because they are medium-sized species that are between 7 and $12 \mathrm{~m}$ high (Silva et al. 1988, Dezzeo et al. 2003, Silva 2013) and rarely reach $\mathrm{Ht}$ higher than $15 \mathrm{~m}$, thus being within the limits calculated for the lower ${ }_{\mathrm{M} 2}(4.0-10.9 \mathrm{~m})$ and mean ${ }_{\mathrm{M} 3}$ $(4.0$ - $9.9 \mathrm{~m})$ strata. In a contact area of the Jaci-Paraná and Madeira Rivers in the state of Rondônia, Reis (2010) observed that trees of Campsiandra laurifolia and Mabea caudata had, on average, 12.0 and $11.0 \mathrm{~m}$, respectively. It is also important to remember that these species are characteristic of the sub-forest (Vieira et al. 2017). This corroborates the observations made, which recorded the presence of only a few shrubs and vines below the canopy of these species. The higher degree of similarity between $\mathrm{M}_{2}$ and $\mathrm{M}_{3}$ is also corroborated from the vertical profiles and distribution trends of the number of trees in the strata. The method $\mathrm{M}_{1}$, for example, grouped the community and species trees in the mean stratum, while in methods $\mathrm{M}_{2}$ and $\mathrm{M}_{3}$ the grouping occurred in the lower stratum, followed by the mean and upper strata, respectively.

The same species, considering the method $M_{1}$, were characteristic of the mean ${ }_{\mathrm{M} 1}$ stratum; however, this behavior seems illogical, based on the results and observations mentioned above. Therefore, considering the boundaries of the lower $_{\mathrm{M} 1}(4-5.9 \mathrm{~m})$ stratum, the mean $\mathrm{Ht}$ of the species Campsiandra laurifolia $(8.0 \pm 3.4 \mathrm{~m})$ and $\mathrm{Ma}$ bea caudata $(7.0 \pm 2.2 \mathrm{~m})$ and the $\mathrm{Ht}$ obtained in other surveys (Dezzeo et al. 2003, Reis 2010, Rodrigues et al. 2012), one can deduce that the upper limit of the lower $_{\mathrm{M} 1}$ stratum was not correctly estimated, as observed through the discriminant analysis, which revealed that one of the height classes was wrongly allocated in the mean ${ }_{\mathrm{M} 1}$ stratum, resulting in a hit rate of $88.9 \%$. The probable reason for this situation was the significant deviation of $\mathrm{Ht}$ from a standard normal distribution. It is also important to remember that, for the evaluated methods, the hit rate should not necessarily be $100 \%$, due to difficulties in obtaining the total tree $\mathrm{Ht}$ in natural forests of the Amazon, which, consequently, adds errors to the calculation of the limits of the Ht strata. Curto et al. (2013) and Silva et al. (2019) show that the height estimate performed visually by an inexperienced and experienced person, respectively, tends to underestimate the height of the trees. It is not affirmed that the method $M_{1}$ is the same as the others, because this depends on other analyses; nonetheless, that $88.9 \%$ fit for the stratum mean ${ }_{\mathrm{Ml}}$ and $95.2 \%$ for the method $\mathrm{M}_{1}$ may not be a bad result.

The method $M_{1}$ assumes that $\mathrm{Ht}$ should follow a standard normal distribution, considering a standard deviation of mean, however the effects of rejection of this assumption did not influence the order of ecological importance of the main species, since, independently of the applied method, the first thirteen species, in descending order, were the same, and these represented more than $70 \%$ of the VIAs. The changes recorded from the 13th species were not large, around two positions for more or less, because the VIA is more influenced by the horizontal parameters, i.e., frequency, density and absolute dominance, which, consequently, end up attributing lower weight to the vertical parameters, that is, absolute sociological posi- 


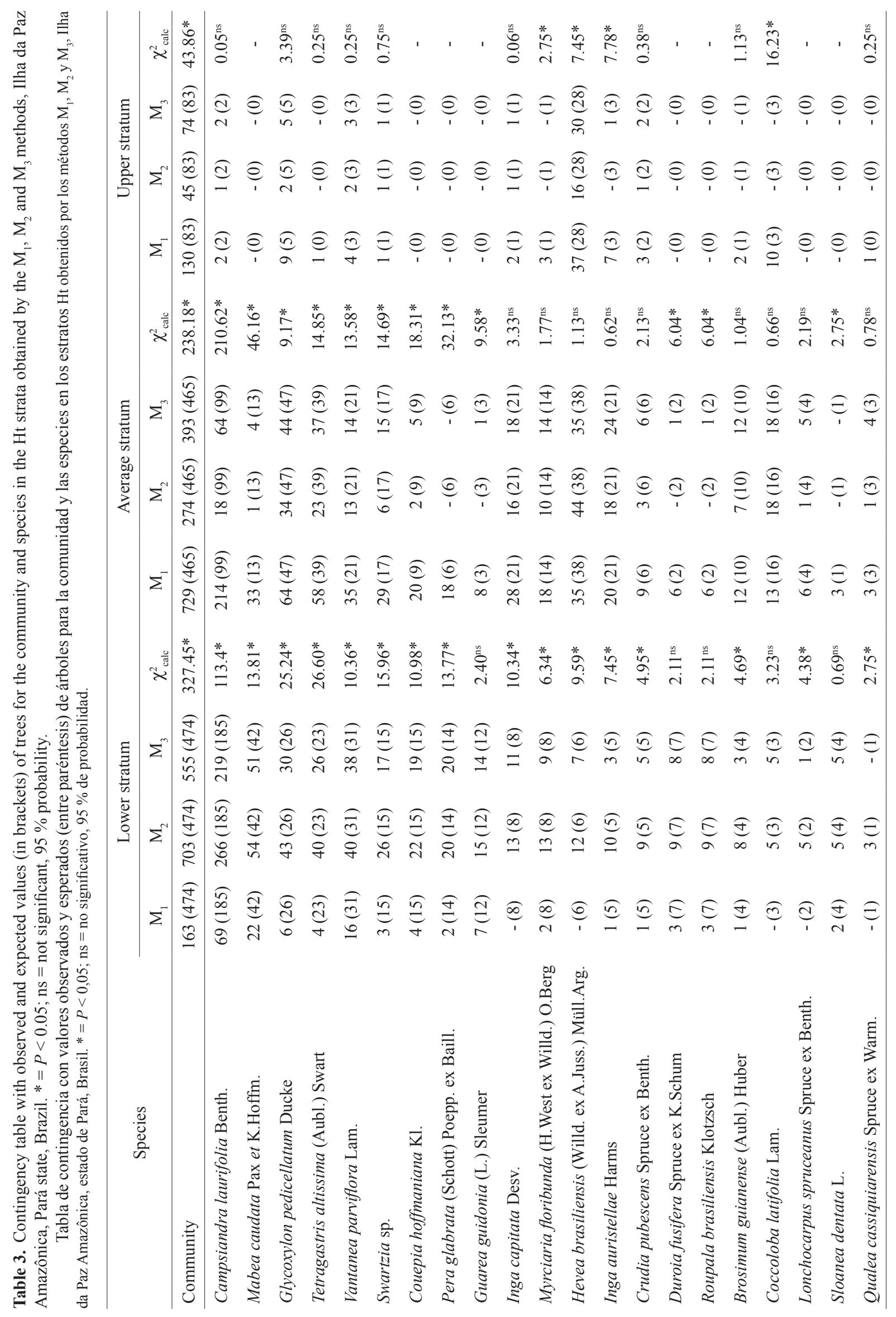


tion (PSA). Such justification helps to understand why the VIA of species among methods $M_{1}, M_{2}$ and $M_{3}$ were very similar, although the chi-square test for contingency tables pointed out significant differences between the number of trees in the strata obtained by the three methods for all the most ecologically important species in Ilha da Paz Amazônica. It is also probable that in very heterogeneous forests, that is, in those where there is no dominion of a group of species, the differences in the structures are more significant, changing even the species of superior ecological importance due to the balance among the parameters that constitute the VIA, mainly PSA.

The vertical strata obtained by methods $M_{2}$ and $M_{3}$ were more similar in all criteria and better than the method $\mathrm{M}_{1}$, which indicates that the use of Lorey height (HL) is a viable alternative for cases in which the Ht data do not follow a standard normal curve. The method $\mathrm{M}_{1}$, although it did not meet its basic assumption, showed that its vertical structure was very similar to those obtained by the others, since in practice they are used to describe the species with the highest frequency, density and dominance and with the best sociological positions (Freitas y Magalhães 2012). This, among the methods, did not present much difference, resulting in the same conclusions that can be obtained from the vertical structures of methods $\mathrm{M}_{2}$ and $\mathrm{M}_{3}$. For example, if there was a need to select species for recovery of floodplain areas in Tapajós River Basin, the recommended species according to methods $\mathrm{M}_{1}, \mathrm{M}_{2}$ and $\mathrm{M}_{3}$ would be Campsiandra laurifolia, Mabea caudata and Tetragastris altissima, as they are dominant, ecologically important and characteristics of wetlands (Ferreira y Prance 1998).

Another conclusion obtained from the three structures, showing their similarities, is that the selection of the species Hevea brasiliensis should be cautious, since places with excessive humidity are the least indicated for their planting, since they provide ideal conditions for the incidence of diseases that limit the growth and survival of smaller trees (Vieira et al. 2017). The structures of methods $\mathrm{M}_{2}$ and $\mathrm{M}_{3}$ demonstrate that Hevea brasiliensis is not abundant in lower ${ }_{\mathrm{M} 2}$ stratum. Regarding lower ${ }_{\mathrm{M} 1}$ stratum, the method $\mathrm{M}_{1}$ it is totally absent, showing that some process generated a high mortality rate of smaller trees of this species. Evaluating forest phytosociology in this same area of study, Vieira et al. (2017) stated that the low abundance of $\mathrm{He}$ vea brasiliensis in the lower stratum is a result of the high flood levels of Tapajós River observed since 2003, while the high abundance in the mean and upper strata occurred due to the low levels recorded between 1970 and 2003, period during which the higher areas would have provided edaphic conditions for the establishment of this species.

Therefore, it is recommended that the method $M_{3}$ be used first, since it is more practical and provides the same results as those obtained from the method $\mathrm{M}_{2}$, which requires a higher level of statistical knowledge. On the other hand, if the objective is more detailed strata, the best option is the method $\mathrm{M}_{2}$ because it allows obtaining more than three strata. In this study, for example, up to five strata with a $100 \%$ correct classification can be obtained, according to Fisher's discriminant analysis. The method $\mathrm{M}_{1}$ can be used in vertical structural analyses, nonetheless it is recommended to evaluate its basic assumption, so that a more coherent stratification is achieved. The results of this study also raise questions to be worked on in the future, on the real importance of evaluating the vertical structure of forests, since the horizontal parameters exert a superior influence on the VIA. In this case, would it be better to evaluate only the horizontal structure or propose an expression where all VIA parameters have equal importance?

\section{CONCLUSIONS}

The methods that consider the cluster analysis and the mean Lorey height were better than the arithmetic mean and standard deviation of the $\mathrm{Ht}$, allowing a more coherent stratification and discussion about the behavior of the species in the community. The arithmetic mean and standard deviation of the $\mathrm{Ht}$ can be used in vertical structural analyses of forests, however, it is recommended to evaluate their basic assumption. The use of Lorey's mean height is operationally feasible for stratification of unequal forests, and can be used in the structural analyses of forests.

\section{REFERENCES}

Alvares CA, JL Stape, PC Sentelhas, JLM Gonçalves, G Sparovek. 2013. Köppen's climate classification map for Brazil. Meteorologische Zeitschrift 22(6): 711-728. DOI: https:// dx.doi.org/10.1127/0941-2948/2013/0507

Angiosperm Phylogeny Group. 2009. An update of the Angiosperm Phylogeny Group classification for the orders and families of flowering plants: APG III. Botanical Journal of the Linnean Society 161(1): 105-121. DOI: https://doi. org/10.1111/boj.12385

Brito A, MZ Ferreira, JM Mello, JRS Pinto. 2007. Comparação entre os métodos de quadrantes e prodan para análises florística, fitossociológica e volumétrica. Cerne 13(4): 399-405.

Calegário N, JRS Scolforo, AL Souza. 1994. Estratificação em altura para floresta natural heterogênea: um proposta metodológica. Cerne 1(1): 58-63.

Curto RDA, GF Silva, JEM Pezzopane, JF Chichorro, R Môra. 2013. Métodos de estratificação vertical em Floresta Estacional Semidecidual. Ciência Florestal 23(4): 643-654. DOI: https://doi.org/10.5902/1980509812348

Dezzeo N, M Worbes, I Ishii, R Herrera. 2003. Annual tree rings revealed by radiocarbon dating in seasonally flooded forest of the Mapire River, a tributary of the lower Orinoco River, Venezuela. Plant Ecology 168:165-175. DOI: https://doi. org/10.1023/A:1024417610776

Durigan G, GADC Franco, M Saito, JB Baitello. 2000. Estrutura e diversidade do componente arbóreo da floresta na Estação Ecológica dos Caetetus, Gália, SP. Revista Brasileira de Botânica 23(4): 371-383. DOI: https://doi.org/10.1590/ S0100-84042000000400003

Ferreira LV, GT Prance. 1998. Structure and species richness of low-diversity floodplain forest on the Rio Tapajós, Eastern 
Amazonia, Brazil. Biodiversity \& Conservation 7: 585-596. DOI: https://doi.org/10.1023/A:1008848200441

Freitas WK, LM Magalhães. 2012. Métodos e parâmetros para estudo da vegetação com ênfase no estrato arbóreo. Floresta e Ambiente 19(4): 520-540. DOI: https://doi.org/10.4322/ floram.2012.054

Ligges U, M Mächler. 2003. Scatterplot3d - an R package for visualizing multivariate data. Journal of Statistical Software 8(11): 1-20. DOI: http://dx.doi.org/10.18637/jss.v008.i11

Lorey T. 1878. Die mittlere bestandeshöhe. Allgemeine Forstund Jagdzeitung 54:149-155.

Oksanen J, FG Blanchet, R Kindt, P Legendre, PR Minchin, RB O’Hara, GL Simpson, P Solymos, MHH Stevens, E Szoecs, H Wagner. 2018. Vegan: Community Ecology Package. R package version 2.5-2. Available in https://cran.r-project. org $/$ package $=$ vegan

R Core Team. 2018. R: A language and environment for statistical computing. R Foundation for Statistical Computing, Vienna, Austria. Consulted 13 Aug. 2019. Available in https:// www.r-project.org/

Reis NFC. 2010. Estrutura fitossociológica e seletividade de espécies em áreas inundáveis na região do Baixo Rio Jaci-Paraná, Rondônia. Tesis Engenheiro Florestal. Porto Velho, Brasil. Falcudade de Ciências Agrárias, Universidade Federal Rondônia. 107 p.

Rodrigues MS, RC Martins-da-Silva, RS Secco. 2012. Caesalpinieae (Leguminosae-Caesalpinioideae) do Campo Experimental da Embrapa Amazônia Oriental, Município de Moju, PA, Brasil. Hoehnea 39(3): 489-516. DOI: https:// doi.org/10.1590/S2236-89062012000300009

Santos LS, LG Martorano, CBB Gutierrez, AN Ponte, OM Silva,
DMG Gutierrez. 2017. Aspecto Fisiográficos da Floresta Nacional do Tapajós e seu Entorno - Oeste do Pará, Brasil. Revista Espacios 38(2): 26-36.

Silva JC, Mendonça AR, Silva GF, Curto RDA, Figueiredo LTM, Silva MLM. 2019. Métodos de medição da altura comercial de árvores na região amazônica. Scientia Forestalis 47(123): 588-598. DOI: https://doi.org/10.18671/scifor.v47n123.20

Silva MF, GH Goldman, FM Magalhães, FW Moreira, MF Silva, GH Goldman, FM Magalhães, F W Moreira. 1988. Germinação natural de 10 leguminosas arbóreas da Amazônia. Acta Amazonica 18(1/2): 9-26. DOI: https://doi. org/10.1590/1809-43921988182026

Silva S. 2013. Árvores Nativas do Brasil. São Paulo, Brasil. Europa. $168 \mathrm{p}$.

Souza AL. 1990. Estrutura, dinâmica e manejo de florestas tropicais. Viçosa, Brasil. Viçosa. 322 p.

Souza DR, AL Souza. 2004. Estratificação vertical em floresta ombrófila densa de terra firme não explorada, Amazônia Oriental. Revista Árvore 28(5): 691-698. DOI: https://doi. org/10.1590/S0100-67622004000500008

Souza DR, AL Souza, JRV Gama, HG Leite. 2003. Emprego de análise multivariada para estratificação vertical de florestas ineqüiâneas. Revista Árvore 27(1): 59-63. DOI: https://doi. org/10.1590/S0100-67622003000100008

Vieira DS, MLR Oliveira, JRV Gama, ELM Machado, EB Görgens, BL Lafetá, JS Garcia. 2017. Phytosociology of a natural fragment of the floodplain forest in the Lower Tapajós River, Brazil. Bosque 38(2): 357-369. DOI: http://dx.doi. org/10.4067/S0717-92002017000200013

Zar JH. 1996. Biostatistical analysis. New Jersey, United States. Prentice Hall. 662 p. 
